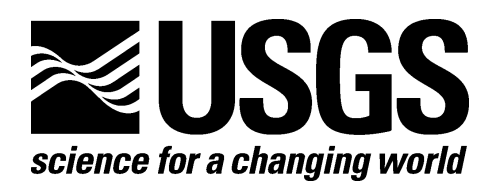

\title{
Chemical analyses of pre-Holocene rocks from Medicine Lake Volcano and vicinity, northern California
}

By Julie M. Donnelly-Nolan

2008

Open-File Report 2008-1094

U.S. Department of the Interior

U.S. Geological Survey 


\section{U.S. Department of the Interior DIRK KEMPTHORNE, Secretary \\ U.S. Geological Survey Mark Myers, Director}

U.S. Geological Survey, Reston, Virginia 2008

For product and ordering information:

World Wide Web: http://www.usgs.gov/pubprod

Telephone: 1-888-ASK-USGS

For more information on the USGS - the Federal source for science about the Earth, its natural and living resources, natural hazards, and the environment: World Wide Web: http://www.usgs.gov

Telephone: 1-888-ASK-USGS

Any use of trade, product, or firm names is for descriptive purposes only and does not imply endorsement by the U.S. Government.

Although this report is in the public domain, permission must be secured from the individual copyright owners to reproduce any copyrighted material contained within this report. 


\section{Contents}

Abstract
Introduction
Methods
Acknowledgements
References Cited

\section{Figures}

1. Map showing area where samples were collected; outline of geologic mapping of Medicine Lake volcano is show; inset map shows location of the volcano

\section{Tables}

1. Chemical analyses of pre-Holocene rocks 


\begin{abstract}
Chemical analyses are presented in an accompanying table (Table 1) for more than 600 pre-Holocene rocks collected at and near Medicine Lake Volcano, northern California. The data include major-element X-ray fluorescence (XRF) analyses for all of the rocks plus XRF trace element data for most samples, and instrumental neutron activation analysis (INAA) trace element data for many samples. In addition, a limited number of analyses of $\mathrm{Na}_{2} \mathrm{O}$ and $\mathrm{K}_{2} \mathrm{O}$ by flame photometry (FP) are included as well as some wet chemical analyses of $\mathrm{FeO}, \mathrm{H}_{2} \mathrm{O}+/-$, and $\mathrm{CO}_{2}$. Latitude and longitude location information is provided for all samples. This data set is intended to accompany the geologic map of Medicine Lake Volcano (Donnelly-Nolan, in press); map unit designations are given for each sample collected from the map area.
\end{abstract}

\title{
INTRODUCTION
}

Medicine Lake Volcano (MLV) is a large Pleistocene and Holocene volcano located in the northern California Cascade Range (Figure 1). In conjunction with geologic mapping of the volcano, rocks were collected for chemical analysis. Analyses from all Holocene map units have been published (Grove and Donnelly-Nolan, 1986; Donnelly-Nolan and Champion, 1987; Grove and others, 1988; Grove and others, 1997; Kinzler and others, 2000). Donnelly-Nolan and others (2007) present the map distribution and revised ages of Holocene and early postglacial lavas. Chemical analyses of early postglacial lavas can be found in Donnelly-Nolan and Champion (1987), Baker and others (1991), and Donnelly-Nolan and others (1991). A limited number of analyses of older lavas were published in Donnelly-Nolan and Champion (1987), Wagner and others (1995), and Elkins Tanton and others (2001); some of these analyses of older lavas are also included in Table 1, but most of the data in Table 1 have not previously been published.

Column A of Table 1 gives sample numbers in consecutive order within each section of the table. All samples were collected by the author with the exception of samples 2B193, 4B543, B8719, and 5B320 which were collected by D.E. Champion as drill cores during sampling for paleomagnetic analysis. Column B gives the designation M (for Medicine Lake) plus in some cases an additional letter. Most such samples are 
pumice lumps collected from unit dta, with some exceptions. Samples 1101M-A and -B and $1471 \mathrm{M}-\mathrm{A}$ and -B are, respectively, porphyritic and finer-grained pairs of samples collected from single outcrops. Samples $1694 \mathrm{M}-\mathrm{A}, \mathrm{B}, \mathrm{C}$ are respectively the lower, middle, and upper tephras collected at one roadcut locality. Samples 828M-B and -C are respectively the white and black tephra collected from a quarry where samples $1501 \mathrm{M}-$ 1503M were also collected.

The accompanying table (Table 1) is divided into three sections, first the chemical analyses of mapped units of MLV; second, units that pre-date MLV but were collected from older units identified on the geologic map; third, other volcanic rocks (all pre-MLV in age) in the area surrounding MLV. Map unit symbols (Donnelly-Nolan, in press) are given in column $\mathrm{C}$.

Latitude and longitude location information is given as minutes and decimal seconds for each sample. In column D, locations are provided with respect to 41 degrees north latitude; in column $\mathrm{E}$ with respect to 121 degrees west longitude. All samples were collected within the area shown in Figure 1. However, only a few samples were located using GPS (Global Positioning System) technology. Most samples were located by inspection on 15-minute topographic maps, the only topographic maps available during most of the time period when the rocks were collected. Locations were then measured by hand and typed into the spreadsheet of data. Thus, locations may be only approximate, and some may be in error.

Analytical data are tabulated in columns F through BG. Most of the data were provided to the author on typewritten forms, and then typed by the author into the spreadsheet. The data have been checked, but errors in transcription are possible.

\section{METHODS}

Rock samples were collected from outcrops and typically were broken up in the field into 1 to $2 \mathrm{~cm}$ fragments using a hammer, and later chipped into $<0.5 \mathrm{~cm}$ fragments in a small alumina jaw crusher. Samples were powdered in an alumina shatterbox and subsequently analyzed in USGS analytical laboratories in Lakewood, Colorado, in Menlo Park, California, and in Reston, Virginia. 
Major elements were analyzed by wave-length X-Ray fluorescence (XRF; Taggart and others, 1987) in Lakewood by J.S. Wahlberg, J. Taggart, J. Baker, A.J. Bartel, K. Stewart, D.F. Siems, and J.S. Mee. In the original major element analyses, all iron was reported as $\mathrm{Fe}_{2} \mathrm{O}_{3}$. The normalized analyses presented in columns $\mathrm{F}$ to $\mathrm{O}$ were calculated by first multiplying the iron value reported as $\mathrm{Fe}_{2} \mathrm{O}_{3}$ by 0.9 to calculate all iron as FeO. Then all major elements were summed without LOI (Loss on Ignition, column Q), resulting in the "original total" (column P). Subsequently, the major elements were recalculated to 100 percent total, volatile-free. The resulting normalized analyses (columns $\mathrm{F}$ to $\mathrm{O}$ ) thus are calculated with all iron as $\mathrm{FeO}$ (in column $\mathrm{H}$, indicated as FeO*). Note that $\mathrm{P}_{2} \mathrm{O}_{5}$ data with values of 0.00 wt. \% in column $\mathrm{N}$ were originally reported as $<0.05$ wt. $\%$.

XRF trace elements reported in Table 1 (columns $X$ to AG) were analyzed by energy-dispersive XRF (Kevex; Siems, 2000) at the chemical analysis laboratory in Menlo Park, California, by P. Bruggman, B. King, and J. Kent, and subsequently in Lakewood by D. Siems, although some data were generated by H.J. Rose, J.R. Lindsay, R. Johnson, B. McCall, G. Sellers, and D. Burgi by wave-length dispersive XRF in Reston, Virginia. At low concentrations, some of these data (e.g. Nb) have large errors. Flame photometry (FP) analyses of $\mathrm{Na}_{2} \mathrm{O}$ and $\mathrm{K}_{2} \mathrm{O}$ (columns $\mathrm{R}$ and $\mathrm{S}$ ) were obtained for a subset of the samples; these analyses were performed by L. Espos, P. Klock, and T. Fries in Menlo Park, California. Also presented in Table 1 are a limited number of wet chemical analyses of $\mathrm{FeO}, \mathrm{H}_{2} \mathrm{O}+, \mathrm{H}_{2} \mathrm{O}-$, and $\mathrm{CO}_{2}$ (columns $\mathrm{T}$ to $\mathrm{W}$ ) in weight percent, performed in Lakewood by L. Jackson, G. Mason, and J. Ryder, and in Menlo Park by W. Updegrove, S. Neil, L. Espos, P. Klock, and T. Fries.

Instrumental Neutron Activation trace element analyses (INAA; Budahn and Wandless, 2002) are presented in columns AH to BG. The analyses were performed in Reston by C. Palmer, G. Wandless, P. Baedecker, J.S. Mee, and L Schwarz, and in Denver by D. McKown, J. Budahn, R. Knight, and H. Millard, Jr.

Precision and accuracy of similar data generated for Crater Lake lavas are reported and discussed in Bacon and Druitt (1988). 


\section{ACKNOWLEDGMENTS}

Funding for this work was provided by the USGS Geothermal and Volcano

Hazards Programs. I thank W. Loskutoff and others for help with sample preparation. D. Ramsey prepared Figure 1.

\section{REFERENCES CITED}

Bacon, C.R., Bruggman, P.E., Christiansen, R.L., Clynne, M.A., Donnelly-Nolan, J.M., and Hildreth, W., 1997. Primitive magmas at five Cascade volcanic fields: melts from hot, heterogeneous sub-arc mantle. Canadian Mineralogist, v. 35, p. $397-$ 423.

Bacon, C.R., and Druitt, T.H., 1988, Compositional evolution of the zoned calcalkaline magma chamber of Mount Mazama, Crater Lake, Oregon: Contributions to Mineralogy and Petrology, v. 98, p. 224-256.

Baker, M.B., Grove, T.L., Kinzler, R.J., Donnelly-Nolan, J.M., and Wandless, G.A., 1991, Origin of compositional zonation (high-alumina basalt to basaltic andesite) in the Giant Crater lava field, Medicine Lake volcano, northern California. Journal of Geophysical Research, v. 96 (B13), p. 21,819-21,842.

Brophy, J.G., Dorais, M.J., Donnelly-Nolan, J., and Singer, B.S., 1996, Plagioclase zonation styles in hornblende gabbro inclusions from Little Glass Mountain, Medicine Lake volcano, California: implications for fractionation mechanisms and the formation of composition gaps. Contributions to Mineralogy and Petrology, v. 126, p. 121-136.

Budahn, J.R., and Wandless, G.A., 2002, Instrumental neutron activation by long count: U.S. Geological Survey Open-File Report 2002-0223, pp. X1-X13.

Donnelly-Nolan, J.M., 2006, Chemical analyses and K-Ar ages of samples from 13 drill holes, Medicine Lake volcano, California. U.S. Geological Survey Open-File Report 2006-1041, 20 p.

Donnelly-Nolan, J.M., Nathenson, M., Champion, D.E., Ramsey, D.W., Lowenstern, J.B., and Ewert, J.W., 2007, Volcano hazards assessment for Medicine Lake volcano, northern California. U.S. Geological Survey Scientific Investigations Report 2007-5174-A, 26 pp.

Donnelly-Nolan, J.M., in press, Geologic map of Medicine Lake volcano, northern California. U.S. Geological Survey Scientific Investigations Map 2927, scale $1: 50,000$.

Donnelly-Nolan, J.M., and Champion, D.E., 1987, Geologic map of Lava Beds National Monument, northern California. U.S. Geological Survey Map I-1804, scale $1: 24,000$.

Donnelly-Nolan, J.M., Champion, D.E., Grove, T.L., Baker, M.B., Taggart, J.E., Jr., and Bruggman, P.E., 1991, The Giant Crater lava field: Geology and geochemistry of a compositionally zoned, high-alumina basalt to basaltic andesite eruption at Medicine Lake volcano, California. Journal of Geophysical Research, v. 96 (B13), p. 21,843-21,863. 
Elkins Tanton, L.T., Grove, T.L., and Donnelly-Nolan, J., 2001. Hot, shallow mantle melting under the Cascades volcanic arc. Geology, v. 29 (7), p. 631-634.

Grove, T.L., and Donnelly-Nolan, J.M., 1986, The evolution of young silicic lavas at Medicine Lake volcano, California: Implications for the origin of compositional gaps in calc-alkaline series lavas. Contributions to Mineralogy and Petrology, v. 92, p. 281-302.

Grove, T.L., Donnelly-Nolan, J.M., and Housh, T., 1997, Magmatic processes that generated the rhyolite of Glass Mountain, Medicine Lake volcano, N. California. Contributions to Mineralogy and Petrology, v. 127, p. 205-223.

Grove, T.L., Kinzler, R.J., Baker, M.B., Donnelly-Nolan, J.M., and Lesher, C.E., 1988. Assimilation of granite by basaltic magma at Burnt Lava flow, Medicine Lake volcano, northern California: Decoupling of heat and mass transfer. Contributions to Mineralogy and Petrology, v. 99, p. 320-343.

Kinzler, R.J., Donnelly-Nolan, J.M., and Grove, T.L., 2000. Late Holocene hydrous mafic magmatism at the Paint Pot Crater and Callahan flows, Medicine Lake volcano, N. California and the influence of $\mathrm{H}_{2} \mathrm{O}$ in the generation of silicic magmas. Contributions to Mineralogy and Petrology, v. 138, p. 1-16.

Siems, D.F., 2000, The determination of 30 elements in geological materials by energydispersive X-ray fluorescence spectrometry: U.S. Geological Survey Open-File Report OF 00-475, 13 pp.

Taggart, J.E., Jr., Lindsey, J.R., Scott, B.A., Vivit, D.V., Bartel, A.J., and Stewart, K.C., 1987, Analysis of geologic materials by wavelength-dispersive X-ray fluorescence spectrometry, in Baedecker, P.A., Methods for geochemical analyses: U.S. Geological Survey Professional Paper 1770, p. E1-E19.

Wagner, T.P., Donnelly-Nolan, J.M., and Grove, T.L., 1995. Evidence of hydrous differentiation and crystal accumulation in the low-MgO, high- $\mathrm{Al}_{2} \mathrm{O}_{3}$ Lake Basalt from Medicine Lake volcano, California. Contributions to Mineralogy and Petrology, v. 121, p. 201-216. 


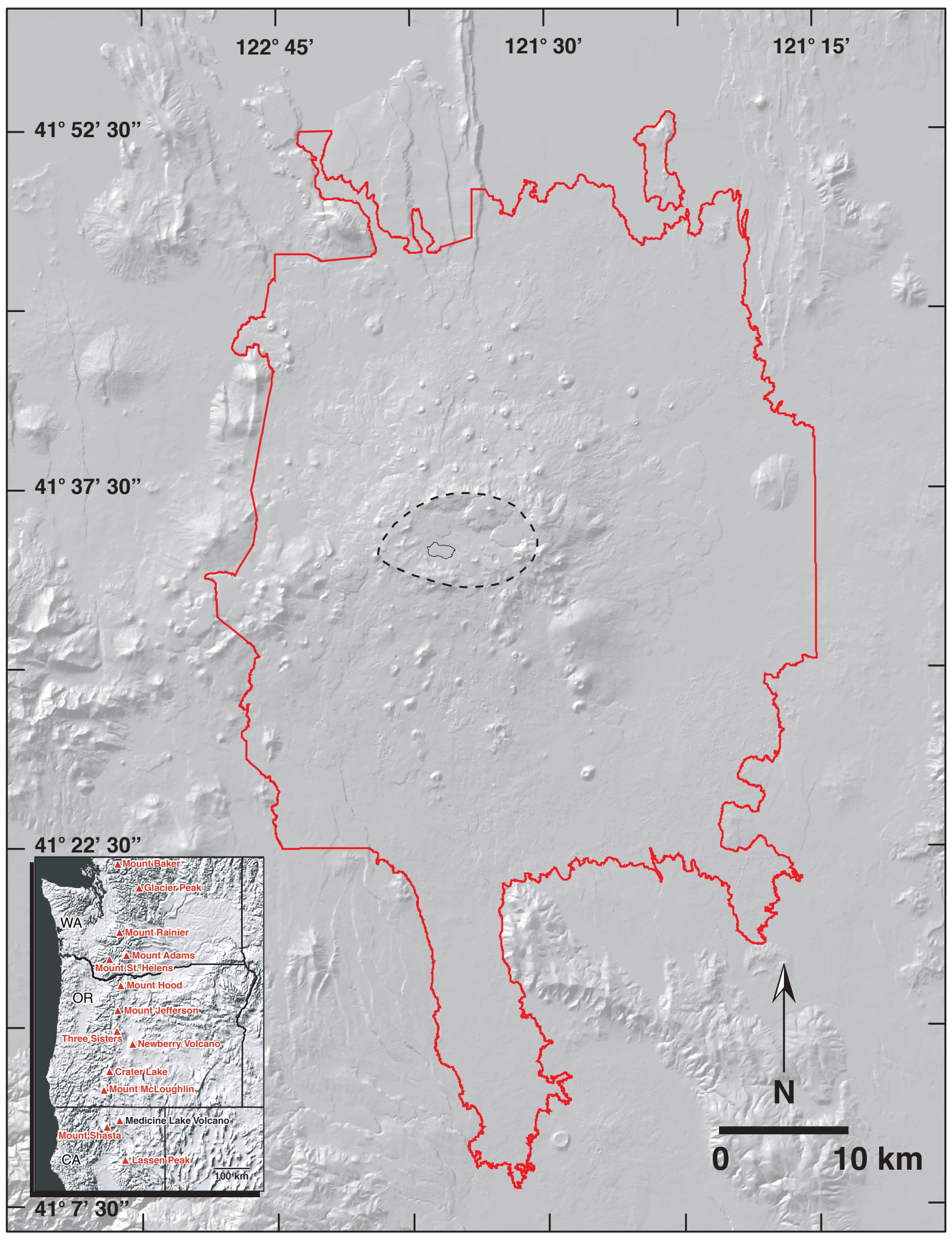

Figure 1. Map showing area in which samples reported in Table 1 were collected. Red outline indicates area of geologic mapping of Medicine Lake Volcano (Donnelly-Nolan, in press). Dashed black line is rim of Medicine Lake caldera. Inset map shows major Cascade volcanoes; Medicine Lake Volcano is indicated with black text. 